\title{
Twenty-five Years Ago
}

From the Supplement, 16 November 1946

\section{A BUSY COUNCII}

The November meeting of the Council was one of the busiest of recent years. There were several important debates, and several committees were set up to carry matters further. One committee was set up to investigate the provision for the care of the elderly and infirm-in two words, the chronic sick. Another was given the task of formulating for submission to the Ministry of Education proposals for the revision of the scale of fees for the medical treatment of school-children. The "closed shop" and the general question of trade unionism and the profession were assigned to another special committee. A fourth committee, as stated above, was the "hardship" or "ways and means" committee. Two important reports, one of them on the reform of the General Medical Council and the other from the Psychiatry and Law Committee recommending the abolition of corporal punishment, came on late in the day, and, a division of opinion developing on both these subjects, it was considered expedient to adjourn them to an extra meeting of the Council to be held on the second Wednes- day of December. By that time it should be possible to announce the first results of the plebiscite.

\section{CORRECTIONS}

R.C.N./B.M.A. Conference

In the announcement of the R.C.N./B.M.A. Conference: "Partners in Patient Care" (Supplement, 30 October, p. 21), Dr. H. J. Galbraith, one of the speakers, was described in error as a general practitioner; he is in fact a consultant physician.

\section{Association Notices}

\section{Diary of Central Meetings}

NOVEMBER

16 Tues. Panel on Biological Advances and Technological Devlopments (Board of Science and Education), 10.30 a.m.

17 Wed. Working Party on Functions of G.M.C., 10.30 a.m.

17 Wed. Panel on the Working of the Abortion Act (Board of Science and Education), 11.30 a.m.

18 Thurs. General Medical Services Committee, 10 a.m.

18 Thurs. Executive Subcommittee (C.C.H.M.S.), 10 a.m. 18 Thurs. Nice (G.M.S.), 1 p.m. 1 p.m.

Working Group on the Functions of the G.M.C. (G.M.S.), 10 a.m.

Local Medical Committees Conference Agenda Committee, 2 p.m.

19 Fri.

\section{Branch and Division Meetings to be Held}

Members proposing to attend meetings marked * are asked to notify in advance the honorary secretary concerned.

Armagh and West Down Division.-At Banbridge Hospital, Tuesday, 16 November, 8.15 p.m., clinical meeting.

Belfast Division.-At 609 Ormeau Road, Thursday, 18 November, 8.30 p.m., Northerp Ireland Plastic and Maxillofacial Service, short papers illustrated by film.

papers illustrated by film. Tuesday, 16 November, 8 p.m., Dr. F. Adrian Ive: "Tropical Dermatology."

Briohton and Mid-Sussex Division.-At Sussex Postgraduate Medical Centre, Wednesday, 17 November, 8.30 p.m., jointly with B.D.A., Dr. J. Hartland: "Hypnosis and its place in Modern Medicine and Dentistry."

Buckinghamshire Division.-At Stoke Mandeville Hospital, Friday, 19 November, 8.30 p.m., Mr. P. D. Trevor Roper: "The Influence of Eye Disease on the Artist." (Preceded by buffet supper at 7.30 p.m. by courtesy of Ciba Laboratories.)

Cambs and Hunts Branch.-At Keynes Hall, King's College, Cambridge, Wednesday, 17 November, 8.30 p.m. Jointly with Cambridge Medical Society, Dr. Michael O'Donnell: 'Looking Sideways at Medical Journalism." (Preceded by buffet supper.)*

Coventry Division.-At Posteraduate Centre, Coventry and Warwickshire Hospital, Tuesday 16 November, 8.15 p.m., Mr. Harry Wheatcroft: "Roses and Gardening." Wives welcome. (Preceded by dinner, 6.45 for 7 p.m.*)

Dorset Division. - At Postgraduate Medical Centre, Dorchester, Wednesday, 17 November, 8 for 8.30 p.m., Dr. Alan J. Rowe: "The Common Market, and Its Effects on our Medical Services." (Preceded by dinner, 7 p.m., Kings Arms Hotel.)

Dorset Division.-At Gloucester Hotel, Weymouth, Friday, 19 November, 7.30 for 8 p.m., joint buffet dance with the Law Society. Tickets £3.00 per head, obtainable from Dr. K. W. Abel, Long Cottage, Walditch, Bridport, Dorset.

East Kent Division.-At Chaucer Hotel, Canterbury, Thursdav, 18 November, 7.30 for 8 p.m., medicolegal dinner. Speaker, Dr. G. L. B. Thurston.*

East Suffolk Branch.-At Postgraduate Medical Centre, Ipswich Hospital, Anglesea Road Wing, Tuesday, 16 November, 8.30 p.m., jointly with Ipswich and Suffolk Branch of the Pharmaceutical Society, spon- sored by Berk Pharmaceuticals Ltd., Sir Derrick Dunlop: "The Safety of Medicines." (Preceded by buffet supper.)

Havering Division. - At Harold Wood Hospital, Friday, 19 November, 8.15 for 8.30 p.m. Dr. W. J. S. Ewan and Dr. John Fry: "The G.P.-Consultant Relationship."

Lancaster Division.-At Postgraduate Medical Centre, Ashton Road, Tuesday, 16 November, 8 p.m., general meeting.

Leigh Division.- At Paddington House Hotel, Warrington, Friday, 19 November, 8 for 8.30 p.m. Annual dinner dance. Guests are invited.*

Lincolnshire Branch.-At St. John's Hospital, Bracebridge Heath,

Lincoln, Saturday, 20 November, 7.30 for 8 p.m., B.M.A. Lecture by Mr. A. Lawrence' Abel: "Blood-Letting Through the Ages."

Maidstone Division.-At Police Headquarters, Maidstone, Tuesday, 16 November, 8 p.m., wine and cheese party.*

Medway and Gravesend Division.-At Central Hotel, Gillingham, Tuesday, 16 November, 7.45 p.m., social evening and talk: "19th Century Art and Victoriana." Guests are invited.*

North Bedfordshire Division.-At the Medical Institute, Thursday, 18 November, 8.30 p.m., jointly with Bedford Medical Society, Sir Ronald Tunbridge: "The Social Worker and the Clinician."

North Middlesex Division.-At the North Middlesex Hospital, London N.18, Tuesday, 16 November, 2 p.m. Clinical meeting.

North Northumberland Division.- At the Consulting Rooms, Alnwick, Friday, 19 November, 8.30 p.m., Dr. R. M. Turner:" "The Thames Mead Experiment."

Nuneaton Division. - At the Manor Hospital, Tuesday, 16 November,

8 p.m., surgical symposium, speakers Mr. J. J. Corkery, Mr. A. Rhodes, Mr. R. E. Shaw, Dr. B. G. P. Macnamara.

Reading Division.-At Royal Berkshire Hospital, Reading, Wednesday, 17 November, 8.30 p.m., Dr. K. Bryn Thomas: "Anatomical Elephants." Wives welcome. (Preceded by meeting to elect representatives for A.R.M., Southampton).

Renfrewshire Division.-At Brabloch Hotel, Paisley, Wednesday, 17 November, 8 p.m., B.M.A. Lecture by Dr. Henry Matthew: "Acute and Chronic Poisoning."

South Bedfordshire Division.-At Luton Medical Centre, Tuesday, 16 November, 8.30 p.m., ioint meeting with the Law Society, Professor John A. Stallworthy: "The Changing Pattern of Medical Litigation." South East Essex Division.-At Admiral's Room. Cliffs Pavilion, Tuesday, 16 November, 7.30 for 8 p.m. Dinner and lecture by Mr. P. D. Trevor-Roper: "The Influence of Eye Disease on the Artist.", South Middlesex Division.-(1) At Jolly Gardeners, Isleworth, WedSouth Middlesex Division.- (1) At Jolly Gardeners, Isleworth, Wed-
nesday, 17 November. 8.45 p.m., joint meeting with British Dental nesday, 17 November. 8.45 p.m.; joint meeting with British Dental Dentistry." (Preceded by dinner, 7.30 p.m.*) (2) At Ashford Hospital Dentistry." (Preceded by dinner, 7.30 p.m.*) (2) At Ashford Hospital
Medical Centre, Saturday, 20 November, 8.30 p.m., wine and cheese evening. Guests are invited *

Svtton Coldfield, Lichfield, and Tamworth Division.-At Good Hope Hospital, Sutton Coldfield, Thursday, 18 November, 8.30 p.m., Dr. Rosemary Rue: "The Place of Women in Society Today." Guests are invited.

Trowbridge Division.-At Bear Hotel, Devizes, Wednesday, 17 November, 8 p.m., B.M.A., Lecture by Mr. Peter Steele: "Medical Problems at High Altitudes."

Tyneside Division.-At Grand Hotel, Tynemouth, Thursday, 18 November, 8 for 8.30 p.m., B.M.A. Lecture by Mr. Brian Harrison: "The Family Service Unit",

Wigan Division.-At Wrightington Hospital, Thursday, 18 November, 8.45 p.m., Professor J. D. Hay: "The Commoner Forms of Congenital Heart Disease."

Wigtownshire Division.-Friday, 19 November, 7.30 p.m., Dr. I. S. Ruthven: "Congenital Abnormalities and Their Management." 